\title{
AVP wt Allele
}

National Cancer Institute

\section{Source}

National Cancer Institute. AVP wt Allele. NCI Thesaurus. Code C52392.

Human AVP wild-type allele is located in the vicinity of 20p13 and is approximately $3 \mathrm{~kb}$ in length. This allele, which encodes vasopressin-neurophysin 2-copeptin protein, is involved in the mediation of a wide variety of bodily functions. Mutations in the gene results in autosomal dominant neurohypophyseal diabetes insipidus. 